\title{
EMPLOYMENT AMONG YOUNG PEOPLE AND GRADUATES IN TERMS OF PERSONNEL STRATEGY
}

\author{
Romana Hricová \\ Technical University of Košice, Faculty of Manufacturing Technologies with a seat in Prešov, Department of Industrial \\ Engineering and Informatics, Bayerova 1, 08001 Prešov, Slovakia, romana.hricova @ tuke.sk
}

Keywords: unemployment, graduate practice, graduate, employee, employer

Abstract: In many countries, after finishing their education, graduates get into an unenviable position when they come out of school, they want to get started and hit the unemployment problem. Many businesses look for employees among those who already have several years of experience, but this gets graduates into a vicious cycle where they cannot obtain work because they have no practice and they have no practice, as they have never worked anywhere. In Slovakia, the situation is not different; Business Insider magazine even ranked Slovakia at the 26th position in the number of unemployed young people from whole world. A state which recognizes seriousness of this situation attempts to change this situation using various means and thus it comes with several programs to reduce unemployment of graduates. This article focuses on such programs as well as a brief evaluation of results.

\section{Introduction}

"Unemployment can be considered a global macrosocial flow generated by causes that have to be the economic situation of users, or the status of tenders for work." [1] A high involuntary unemployment may reflect the fact that the labour market is not a "standard" market. Policy paper - Economic analysis of Unemployment in Slovakia says, that the average rate of Slovak unemployment in the last 20 years reaches $14.5 \%$, well above the majority of European countries. [2] One of the big problems is unemployment of young people. Of course there are also another problems in Slovak conditions (for example very low skills and discrimination exclude Roma population from the labour market; inadequate initial structure of the economy and high contributions and inappropriate tax - benefit system reduces job creation among low-income households) [2], but young people without chance to work means generation without appropriate work habits.

To be clear on who is statistically taken into the category of "young people", it is necessary to define certain terms. There are different age or conceptual definition, but in the document of the European Foundation for the Improvement of Living and Working Conditions [3] there is an abbreviation NEETs (Not in Education, Employment and Training), which includes young people aged 15-29 who are not in employment, not in education and not in training. It means that, those who are studying and constantly preparing for their future careers are excluded from this category. The term NEETs is now used internationally.

The ambitious of the article is to show, how successful tools, which use Slovak republic, are. Data from official Slovakian sources (as for example the Office of Labour, Social Affairs and Family) are used for comparison. Although used data are secondary, there is no accurate method to obtain primary data, as Slovak companies are required by law to provide the information requested. The data used in this article belong to this type of data.

\section{Unemployment of young people - a global problem and a nationwide problem in Slovakia}

European Employment Strategy has as its key policy issue the integration of young people into the labour market. The young people integration into the labour market is a very important objective not only all over the world but mainly in former communist countries of EastCentral Europe [4]. Youth unemployment rates are generally more than twice as high as the adult rates, with significant differences across countries and regions [5]. Youth unemployment dramatically rose again after the recent global economic crisis [6].

On December 3, 2015 Business Insider Magazine published ranking of 47 countries where youth unemployment is critical [7]. Given that many countries do not release a list of their monthly official (nor even annual) economic data, the data from the International Labour Organization were used for the estimate data for 2014. If we only take the European countries, according to the aforementioned statistics the situation in Greece is the worst. In 2014 the youth unemployment rate (estimated) was $64.8 \%$, while the percentage of population aged 1524 is $9.72 \%$ (under 24 years it is $23.73 \%$ ). The second place was taken by Bosnia and Herzegovina, where the estimated rate of unemployment is $60.2 \%$, while the country has $12.36 \%$ of young people aged $15-24$ years (generally $25.84 \%$ under 24 years). Spain is in third place with $58.2 \%$ of youth unemployment and their representation by $9.56 \%$ ( $25.01 \%$ under 24 years). Macedonia is in the 7th place $(54.32 \%)$, number 9 is Croatia (49.5\%), 10 is Serbia (46.6\%), 15 is Montenegro $(40.5 \%), 17$ is Italy (38.3\%), 19 is Cyprus (37.1\%), 21 is 
Portugal $(35.9 \%)$ which brings us to the 26th place taken by Slovakia. Slovakia thus came with its $33.8 \%$ between Jamaica and Suriname. Such a figure is alarming because it says that every third young person under 24 years is unemployed. The situation is even worse because if a young person does not obtain work habits soon after graduation they have a lifelong problem, not only in the work area.

The Statistics Portal „Statista“ shows Youth unemployment rate in Europe (EU member states) as of July 2016 (seasonally adjusted) [8]. The source defines youth unemployment as unemployment of those younger than 25 years and Slovakia is taking the 7th place with $24 \%$.

Young Slovak people solve the problem of unemployment in different ways, typically it is going abroad, and this number is alarming. Years 1980-1990 were baby boomers, because every year about 80 thousand people were born [9]. However, about 30 thousand of them are leaving every year to work and live abroad, which is more than a third. Therefore, it is a responsibility of the State to create such conditions for the young that they do not leave to work abroad but have plenty of job opportunities in Slovakia. It is not possible to officially find out how many Slovak citizens permanently live and work abroad, as this figure is not being recorded by any institution. The most precise statistics are those of the health insurance companies, since every citizen is obliged to pay health insurance. In case a person goes to a foreign country, they must choose which country they will pay health insurance. In 2013, the health insurance system was left by almost 30 thousand people under 30 and roughly the same number left since 2009 every year. This means that within five years about 150,000 young people under 30 years of age went abroad [9]. Since this number is truly alarming, there is an effort to create the conditions that employers were interested in employing young people and those not departed abroad.

\section{Assistance in employment of young people in Slovak republic}

Every organization that wants to operate in the market successfully and for a long time must have a personnel policy that is well formulated and clear, understandable, acceptable, long-term stable both in terms of employees, as well as from the perspective of the surrounding area [10]. The actual personnel policy of a company encompasses many sectional policies such as recruitment and selection of employees, remunerations, education, personal and social development of employees as well as their evaluation. Not to mention that a good organizational personnel policies must also respect the laws and legislation on the rights of workers and their working conditions.

Enterprises are trying to make a profit using various sources, ranging from technology through financial, natural, to know-how, etc., but continuously crucial role is being played by employees; corporate human resources, due to which the company can maintain in the market [10]. Many Slovak companies underestimate this fact, yet a modern organization knows that finding, nurturing and retaining high-quality, efficient and loyal employees can be a key factor for success. That is why more and more businesses seek quality graduates since they have an opportunity to train them according to their own requirements. On the other hand, such training usually takes several weeks to months, while experienced employees need a much shorter time - sometimes several hours are sufficient. On the other hand, lack of experience and skills of young workers can be balanced out by the employer by lower wage costs. On the other hand, it is certainly clear that not every vacancy can be filled by a graduate or a young professional without experience. There are even jobs where experience is necessary. Therefore, human resource management department must know exactly which jobs are suitable for graduates and which are not.

A company recruiting graduates usually faces the question of whether to allocate a new employee to a regular employee, who should help them, train them and, if necessary, check them, or the graduate should remain on their own. Such a decision entails a number of disadvantages, starting with the one that the graduate does not obtain right work habits and ending with the fact that they do not identify with the corporate strategy, they do not meet the demands of the job that may culminate in leaving the position. It means a loss to the company, of course, because it has to start looking for a new graduate and again devote time, energy and often also money to that process. On the other hand, if the graduate is assigned to a regular employee, the employer must realize that he will have to, especially at an early stage of the learning, devote more time to the graduate, which may result in a lower performance in his own work. Therefore, the learning of a graduate should be reflected in the job descriptions of regular employees, so they do not have time constraints and can fulfil their own responsibilities.

Employers are well aware of the disadvantages associated with the employment of graduates and therefore often prefer recruitment of new employees with work experience. On the other hand, there is a social interest of employing young people. It is not only Slovak but Europewide problem, as statistics clearly show that since 2009, the time of the deepest crisis, the situation has stagnated at about $33 \%$ unemployment of young people, which means that around one in three young people is without a job. Because these young people do not gain basic work habits, the phenomenon of so-called "Lost generation" has arisen, a generation that wants to work, but actually cannot. These are not only university graduates or secondary school leavers (although they most contribute to statistics), but the overall problem of a large group of people for whom no jobs have been created. This is one of two main reasons. 
The other reason is incorrectly set fields of study, which are not in the line with labour market needs.

To help companies to employ young people and so to prevent young people from leaving their country to work abroad, the European Commission by means of its implementing Decision CCI 2014SK05M0OP001 dated 9th December 2014 adopted and approved the Operational Programme Human Resources (HR OP), where the role of managing authority is performed by the Ministry of Labour, Social Affairs and Family [11]. The aim of the OP is to promote regional development and to initiate support of youth employment. Funding is from the European Structural and Investment Funds for the programming period 2014-2020. OP itself contains several ways how employers can encourage employment of young people graduates and thanks to that train employees needed for the future. A graduate can be found in some of these contributions offered by the Office of Labour, Social Affairs and Family (which is directly controlled by Ministry of Labour, Social Affairs and Family) [11]:

a) Contribution to support job creation in the first regular paid employment.

The target audience is a job seeker that before the adoption did not have regular paid job, i.e. it did not last for more than 6 consecutive months. An applicant under 25 years of age should be kept in the records for three months, an applicant under 29 for 6 months, with an emphasis on the long-term unemployed job seekers. A financial contribution in this case is provided for at least six months and a maximum of 12 calendar months, and the monthly amount is $80 \%$ of the total labour costs, not more than $€$ 515.40. The employer's obligation in this paper is to maintain the created job at least to the extent corresponding to half of the agreed duration of the contribution (i.e. in providing the financial contribution for six months the job must be maintained for nine months). Job creation means increasing the number of workplaces, i.e. the employer cannot replace existing workplaces. The contribution is provided to the employer monthly by repayment on the basis of submitted documents.

\section{b) Practice leading to employment}

It is contribution for mentored practice by an employer who creates a job for that purpose. The target group of this contribution are young people registered in the register of job seekers; job seekers under 25 should be kept in the records for at least three months and a jobseeker under 29 for at least six months. The Authority subsequently provides refunding to the employer:

- mentoring contribution of a maximum of $€ 68.44$ / 1 mentored employee / one month paid once for the whole period of mentoring,

- contribution to cover part of the total labour cost (TLC) for an employee who has been accepted for mentored training and practice - of no more than $95 \%$ of the TLC, maximum of $€ 273.77$ at 1/2-time employment, provided monthly for the mentored training and practice,
- contribution to cover part of the necessary costs associated with mentored training and practice - e.g. personal protective equipment, protective equipment, working tools, a maximum of $€ 58.06$; it is a single financial contribution for one mentee training and practice.

This contribution may be claimed by the employer who employs a job seeker from an eligible target group for parttime work for at least nine months, or indefinitely, with this contribution being granted for a maximum of nine months.

c) Contribution for graduate practice

This contribution is focused on the acquisition of professional skills and practical experience with an employer, which corresponds to the level of education achieved at school within the group of study branches or fields. A condition for the graduate practice is that a graduate has been on the register of job seekers for at least one month (a graduate means a citizen less than 26 years of age, who has completed the appropriate level of education systematic vocational preparation in full-time study less than 2 years ago and since then had no regularly paid job. This status of graduate must be met by a job seeker throughout graduate practice.

A graduate apply for graduate practice placement and for a contribution at the competent authority within the territorial jurisdiction of their residence. The practice is carried out at least three months and not more than six months without a possibility of renewal and repetition, for 20 hours a week. The beginning of practice as well as its extent is determined by the employer. During the graduate practice, the Office may provide a graduate with contribute a lump sum of $65 \%$ of the subsistence minimum for one adult person (i.e. currently $€ 128.75$ ) per month to cover their essential personal expenses connected with the practice. During the practice a graduate is also entitled to 10 working days of leave. After the practice the employer shall issue a certificate of completion of practice.

d) Graduate practice starts employment - this program consists of two activities:

Activity No. 1 - to provide a financial contribution for graduate practice (3)

Activity No. 2 - providing financial contributions to promote job creation

Activity No. 1 follows the same rules as those mentioned in contribution 3). Then contribution to the employer is made on the basis of submitted documents (attendance records confirmed by the employer and the contract of accident insurance) amounting to $65 \%$ of the subsistence minimum monthly, maximum of $€ 128.75$ and compensation premiums for accident insurance. Financial contribution is made at least three months and not more than six months.

Activity No. 2 is explicitly tied to activity No. 1 and on condition that the employer employs this job seeker without undue delay, within 30 calendar days after the end of the graduate practice. The target group is NEETs under 29 years, who at the time of entry into the program meet the requirement of graduation and must be in the eligible 
area (outside Bratislava Self-Governing Region). The contribution is provided in the amount of the advance on the premium for compulsory health insurance, social insurance and compulsory contributions to superannuation, paid by the employer, a maximum of $€ 302.35$ for the year 2016 on a full time basis. Applicants must be admitted to full-time employment for at least 9 months, or indefinitely, while the benefits are provided for six months.

e) Contribution to support the employment of disadvantaged job seeker

The contribution is granted to an employer by the office in the territory of which the working place is created, if the employer asks for the contribution in writing and the job created is given to a disadvantaged job seeker who has been in the register for at least three months, if the employment relationship is understood at least one half of the set weekly working hours. A disadvantaged job seeker is also a citizen under 26 years of age, having completed the appropriate level of education in systematic vocational preparation in full-time study less than two years ago and before registering as jobseekers had no regular paid employment. The monthly contribution is $40 \%$ of employee TLC calculated from the average wage of employee in economy for I-III quarter of the calendar year preceding the calendar year in which the contribution is made - i.e. $€ 464.54$. (For 2016, the average wage of an employee in the Slovak economy in I-III quarter 2015 is set at $€ 859$ and TLC calculated on the average wage of employees thus is $€$ $1,161.35$. The contribution is provided based on a written agreement for at most 12 calendar months - if a candidate kept in the records of three months is employed; if the employer employs a candidate kept in the records for more than 24 months - contribution is made for no longer than 24 months. The employer must maintain the newly created job, which was tied with a contribution, at least to the extent corresponding to half of the agreed period, providing post, i.e. if the contribution is paid for 12 months, the employment lasts for 18 months; if the contribution is paid 24 months, the employment relationship is concluded for 36 months.

As seen from the survey, the state is trying to assist the employment of young people. Statistics of the Office of Labour, Social Affairs and Family [11] evaluates how many young people do their graduate practice every month.

Table 1 Number of job seekers participating in graduate practice in April and May 2015

\begin{tabular}{|l|l|r|}
\hline \multirow{4}{*}{} & May 2015 & April 2015 \\
\hline
\end{tabular}

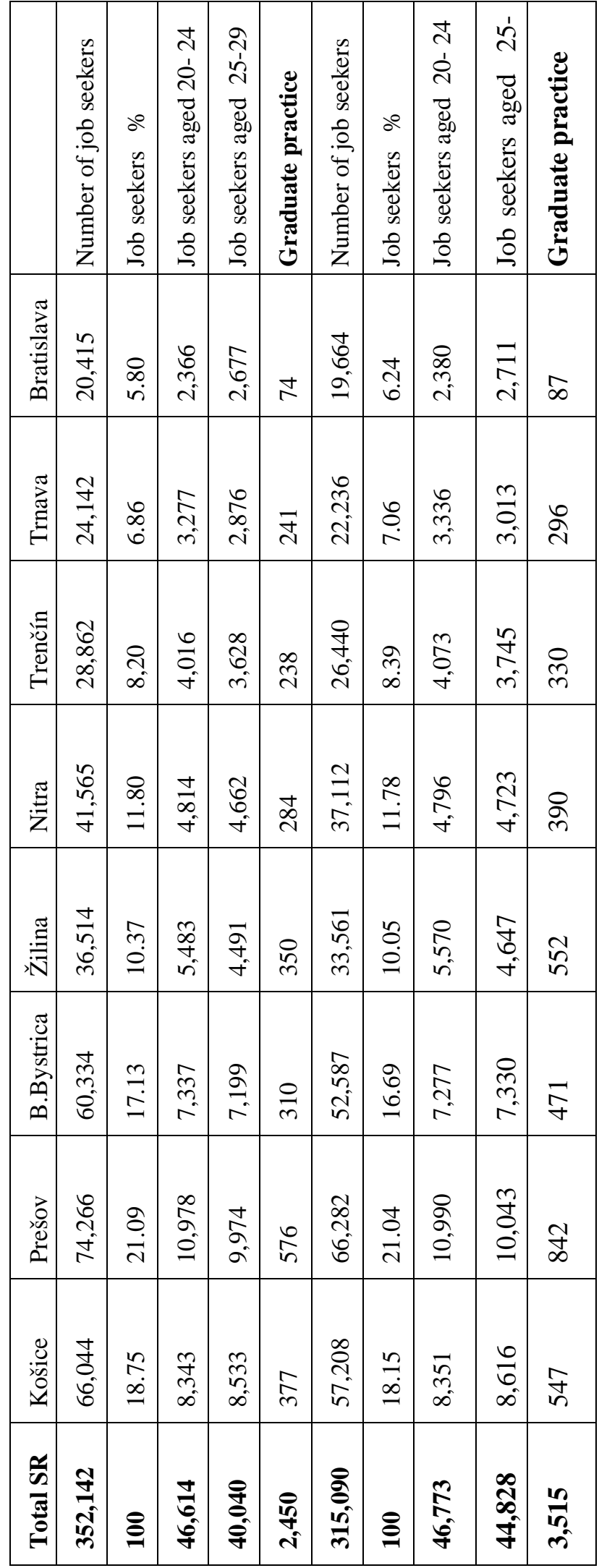

Table 2 Number of job seekers participating in graduate practice in April and May 2016

\begin{tabular}{|l|l|l}
\hline$\propto$ & May 2016 & April 2016 \\
\hline
\end{tabular} 


\begin{tabular}{|c|c|c|c|c|c|c|c|c|c|c|}
\hline & 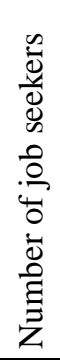 & 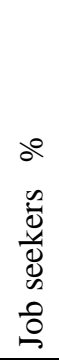 & 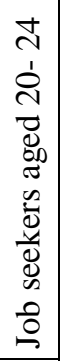 & 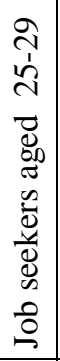 & 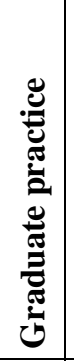 & 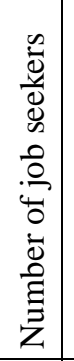 & 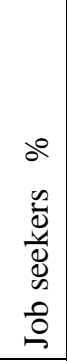 & 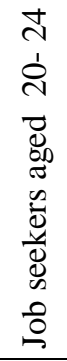 & 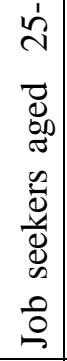 & 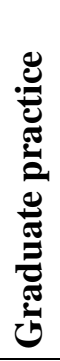 \\
\hline 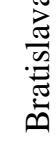 & $\begin{array}{l}\frac{m}{n} \\
\stackrel{n}{n}\end{array}$ & $\stackrel{2}{i n}$ & $\underset{\nabla}{\stackrel{ \pm}{ \pm}}$ & $\begin{array}{c}\overline{\widetilde{Z}} \\
\underset{\mathrm{i}}{\mathrm{i}}\end{array}$ & $\vec{b}$ & $\begin{array}{l}2 \\
2 \\
=\end{array}$ & $\frac{n}{n}$ & $\stackrel{n}{6}$ & $\begin{array}{l}\overrightarrow{\tilde{n}} \\
\tilde{i}\end{array}$ & $\stackrel{n}{r}$ \\
\hline 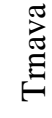 & $\stackrel{\infty}{2}$ & $\stackrel{n}{n}$ & $\begin{array}{l}\vec{m} \\
\text { m. } \\
i\end{array}$ & $\begin{array}{l}\hat{\theta} \\
\hat{i} \\
\hat{i}\end{array}$ & $\stackrel{\wp}{ \pm}$ & $\begin{array}{l}\infty \\
\infty \\
\infty \\
\infty\end{array}$ & 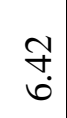 & $\begin{array}{l}\underset{\pi}{d} \\
\underset{i}{i}\end{array}$ & $\begin{array}{l}\hat{0} \\
\tilde{i} \\
i\end{array}$ & $\bar{\nabla}$ \\
\hline 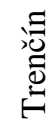 & $\begin{array}{l}\infty \\
0 \\
\tilde{\sigma}\end{array}$ & $\underset{\sim}{\sigma}$ & $\begin{array}{l}+ \\
\infty \\
0 \\
i \\
i\end{array}$ & $\begin{array}{l}\tilde{W} \\
\infty \\
i\end{array}$ & $\hat{6}$ & $\begin{array}{l}\stackrel{N}{ \pm} \\
\underset{N}{N}\end{array}$ & స్ర & $\begin{array}{l}8 \\
\text { do } \\
i\end{array}$ & $\begin{array}{l}\stackrel{\Delta}{~} \\
\hat{i}\end{array}$ & $\stackrel{\mathcal{N}}{\sim}$ \\
\hline$\stackrel{\widetilde{G}}{\mathrm{Z}}$ & $\begin{array}{l}\vec{b} \\
\text { mi }\end{array}$ & $\stackrel{\varrho}{=}$ & $\begin{array}{c}\mathbb{2} \\
m \\
m\end{array}$ & $\begin{array}{l}\bar{n} \\
n \\
m\end{array}$ & Әे & $\begin{array}{l}+ \\
\infty \\
\dot{m}\end{array}$ & 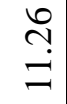 & 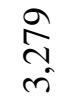 & 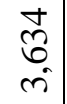 & 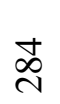 \\
\hline$\stackrel{\mathfrak{G}}{:}$ & $\begin{array}{l}\tilde{f} \\
\text { बे } \\
\stackrel{2}{2}\end{array}$ & $\vec{a}$ & $\begin{array}{l}\text { సి } \\
\infty \\
\text { r }\end{array}$ & $\begin{array}{l}\stackrel{0}{1} \\
\text { r. } \\
\text { n. }\end{array}$ & ঐे & $\begin{array}{l}0 \\
n \\
n \\
0 \\
\tilde{n}\end{array}$ & $\begin{array}{l}\infty \\
\infty \\
\sigma\end{array}$ & 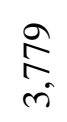 & 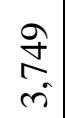 & $\underset{\infty}{\mathbb{n}}$ \\
\hline 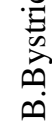 & $\begin{array}{l}0 \\
\infty \\
0 \\
i \\
i\end{array}$ & 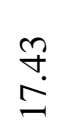 & $\begin{array}{l}\frac{d}{0} \\
i n\end{array}$ & $\begin{array}{l}\hat{\delta} \\
\hat{0}\end{array}$ & $\stackrel{\mathcal{I}}{\sim}$ & 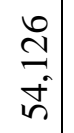 & 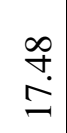 & $\frac{9}{i}$ & $\frac{\sigma}{\sigma}$ & 过 \\
\hline 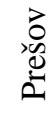 & $\frac{2}{6}$ & 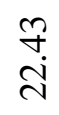 & $\begin{array}{l}\bar{m} \\
a\end{array}$ & $\begin{array}{l}\hat{n} \\
\hat{\sigma} \\
\end{array}$ & হి & $\begin{array}{l}0 \\
\infty \\
\infty \\
0\end{array}$ & 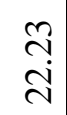 & $\begin{array}{l}n \\
\stackrel{n}{a}\end{array}$ & $\begin{array}{l}\overline{\widehat{\delta}} \\
\stackrel{a}{ }\end{array}$ & $\begin{array}{l}\infty \\
\text { in }\end{array}$ \\
\hline $\begin{array}{l}\mathscr{U} \\
i \overline{0} \\
0 \\
1\end{array}$ & $\begin{array}{l}5 \\
\hat{0}\end{array}$ & $\stackrel{+}{n}$ & 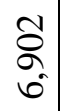 & $\begin{array}{l}n \\
\stackrel{a}{a} \\
r\end{array}$ & तి & $\begin{array}{l}\tilde{\delta} \\
8 \\
8\end{array}$ & ๗ે & $\begin{array}{l}\stackrel{1}{\infty} \\
\infty \\
0\end{array}$ & 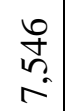 & $\bar{n}$ \\
\hline$\frac{\mathscr{a}}{\frac{\pi}{\sigma}}$ & $\begin{array}{l}\text { J్ర } \\
\text { స̃ } \\
\text { } \\
\text { లి }\end{array}$ & $\stackrel{\theta}{\Theta}$ & $\begin{array}{c}\widetilde{N} \\
\text { हై }\end{array}$ & $\frac{\infty}{\stackrel{\infty}{\sigma}}$ & $\begin{array}{l}\tilde{A} \\
\tilde{-} \\
-\end{array}$ & $\begin{array}{l}\tilde{8} \\
\hat{n} \\
\hat{\rho} \\
\hat{\rho}\end{array}$ & $\stackrel{\Xi}{\Xi}$ & 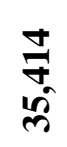 & 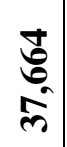 & $\begin{array}{l}\vec{J} \\
\text { i }\end{array}$ \\
\hline
\end{tabular}

Comparing the results of two months in 2015 (Table 1) and 2016 (Table 2) there is a certain tendency of development. Firstly, although the overall unemployment has fallen in 2016, interest in graduate practice has not changed significantly.

Second, in both years, there is apparent decline in interest in graduate practice in the month of May. Surveys on the employers' side, this annual decrease due to the fact that young people prefer foreign brigade in the summer before graduate practice.
Although participants of graduate practice are not counted in the total unemployment rate (which is lower than the total number of job seekers) it shows that there is interest in graduate practice, although it is questionable whether it involvement of graduates is sufficient. In the month of April 2016, 3.61\% (April $2015=3,8 \%$ ) of jobseekers aged 20 to 29 years were involved in graduate practice. In the month of May 2016 it was only $2.50 \%$. (May $2015=2,8 \%$ ) The statistics cannot sort out how many job seekers aged 20 to 29 years qualified for graduate practice, so the percentage would actually be higher.

In addition to that it can be observed that with increasing unemployment across regions, also the number of graduates at the graduation practice is increasing. The only exception is Žilina Region, where in despite of lower unemployment, the graduation practice is higher, which may be related to the industrial character of the region.

\section{Conclusion}

Human resource management in today's society plays an important role because it having the right people in the right positions is the basis for success. Investment in human capital is relatively high, so investors (individuals, organizations and society) occupy a return on investment [13]. Because in most cases the employer can still choose from potential employees, it is necessary that this selection was conducted as accurately as possible with regard not only to the needs of the employing company but also the potential future employee. A job-seeker who has never worked anywhere thus gets to be in a disadvantageous position, since they often have no work experience that many employers take as a disadvantage. HR professionals often say that even at a personal interview with the candidate it is difficult to detect their pros and cons, so a candidate who has already had some practice gets a more favourable position thanks to the work experience. On the other hand, a young graduate with no work experience is often a "blank sheet" who does not bring any improper work habits from a previous job and the employer can teach everything necessary to their liking. Not to mention that the employment of graduates also comes with a societal effect, which consists in the fact that there is no "lost generation" that never worked anywhere and that if the graduate holds good at work, they have an opportunity to obtain a permanent job.

\section{References}

[1] GOGONEA, R.M., ZAHARIA, M., IONESCU, S.A.: Econometric Models Applied in Study of Unemployment Rate Evolution in Romania, Proceedings of the $10^{\text {th }}$ WSEAS International Conference on FUZZY SYSTEMS, Available: http://www.wseas.us/elibrary/conferences/2009/prague/FUZZY/FUZZY18.p df, 2009. 
[2] Unemployment in Slovakia. Economic analysis Policy paper, November 2014, Available: https://www.finance.gov.sk/en/Components/Category Documents/s_LoadDocument.aspx $?$ categoryId $=698 \&$ documentId=605, 2014.

[3] European Foundation for the Improvement of Living and Working Conditions, Available: https://europa.eu/european-union/abouteu/agencies/eurofound_en, 2017.

[4] CHOUDHRY, M.T., MARELLI, E., SIGNORELLI, M.: Youth unemployment rate and impact of financial crises, International Journal of Manpower, Emerald Group Publishing Limited, Vol. 33 No. 1, pp. 76-95, 2012.

[5] QUINTINI, G., MARTIN, J., MARTIN, S.: The changing nature of the school-to-work transition process in OECD countries, IZA Discussion Paper No. 2582, 2007.

[6] ARPAIA, A., CURCI, N.: EU labour market behaviour during the great recession, Economic Papers No. 405, European Economy, European Commission, Economic and Financial Affairs, Brussels. Bonn: Institute for the Study of Labor (IZA). 2010.

[7] HOLODNY, E.: 47 countries where young people are living in an unemployment crisis, Business Insider. Available: http://www.businessinsider.com/countrieswith-worst-youth-unemployment-2015-11, 2015.

[8] Youth unemployment rate in Europe (EU member states) as of August 2017, https://www.statista.com/statistics/266228/youthunemployment-rate-in-eu-countries/, 2017.

[9] http://správy.pravda.sk/domace/clanok/306478-rocneodide-do-cudziny-30-e2-80-93tisic-mladych/, 2017.

[10] KACHAŇÁKOVÁ, A., STACHOVÁ, K., STACHO, Z:: Human resources management in organizations operating in Slovakia, IURA EDITION spol. s r.o., 2013. (Original in Slovak)

[11] https://www.employment.gov.sk/sk, 2017.

[12] ARMSTRONG, M., TAYLOR, S.: Armstrong's Handbook of Human Resource Management Practice, Publisher: Kogan Page, 2014.

[13] KRAVČÁKOVÁ, G. et al.: Organizational behavior, Publisher: Pavol Jozef Šafárik University in Košice, 2015. (Original in Slovak)

\section{Review process}

Single-blind peer reviewed process by two reviewers. 